Copyright (C) 2021 by Cherkas Global University

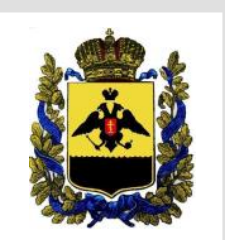

Published in the USA

Bylye Gody

Has been issued since 2006.

E-ISSN: $2310-0028$

2021. 16(4): 1898-1909

DOI: $10.13187 / \mathrm{bg} .2021 .4 .1898$

Journal homepage:

https://bg.cherkasgu.press

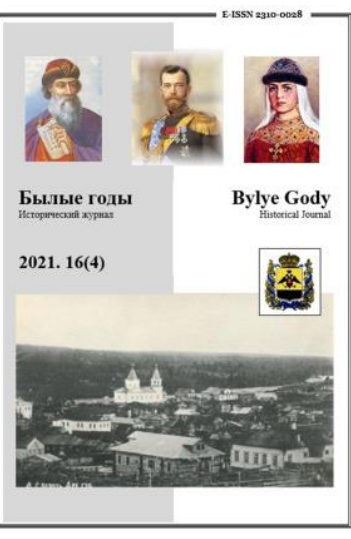

\title{
The Image of China and the Chinese in Late Imperial Russia (based on Materials from the "Niva" Journal)
}

\author{
Andrey A. Avdashkin a , *, Tatyana V. Raeva a, Igor V. Sibiryakov a \\ a South Ural State University, Russian Federation
}

\begin{abstract}
The article examines the images of China and the Chinese in the Russian Empire in the second half of the 19th and early 2oth centuries on the example of "Niva" journal. This journal published news articles, reports from the scene, portrait sketches, literary works on the "Chinese theme", biographical and ethnographic essays. Texts and numerous illustrations showed the history of China, the way of life and traditions of its population to a wide audience. The authors came to the conclusion that the publishers, editors, and authors of the journal, as well as, probably, the pre-revolutionary Russian public failed to form a complete image of the Chinese and state of China. In the aggregate of various, sometimes mutually exclusive, ideas about them, depending on the Russian and world socio-political context of the second half of the XIX early XX centuries certain elements were updated. This explained the volatility of public opinion in Russia in relation to China, the problem of "yellow labor", gave dynamics and flexibility to Russian policy in the Far East and its representation in public space. The images of the state of China and the Chinese were multifaceted and dynamic.

Keywords: image, China, chinese, Niva, yellow peril, migration, Russian empire.

\section{1. Введение}

Зарождение и трансформация образа «другого» в российской истории приобретает особую значимость для понимания эволюции и преемственности идентичности российского общества, создания круга «друзей» и «врагов». Большое значение в содержательном наполнении образа Китая и китайских мигрантов играла пресса. Тексты, разоблачающие образ «другого» в позднеимперской России, часто имели более влиятельный и долгосрочный мировоззренческий эффект, нежели планировали их авторы (Дятлов, 2014). Так в массовое сознание внедрялись националистические максимы, отразившие напряженность модернизации и формирования национальной идентичности.

Роль дореволюционной периодики в выработке отношения к китайцам уже подробна изучена, но мы по-прежнему наблюдаем ряд содержательных лакун. В фокусе внимания историков остается ограниченный массив наиболее известных текстов. Расширение источниковой базы позволит ответить на важные вопросы: насколько массово и интенсивно внедрялись в общество представления и образы китайцев, в каких контекстах и как они конструировались, какие сюжеты и оценки являлись основополагающими для российского общества того времени.
\end{abstract}

\section{2. Материалы и методы}

Журнал «Нива» относится к наиболее популярным и при этом слабо изученным изданиям дореволюционной России. Он выходил еженедельно в Санкт-Петербурге с 1870 по 1918 гг. В отличие от аналогичных общественно-литературных (литературно-политических) журналов, таких как «Вестник Европы», «Русское богатство», «Русская мысль», «Русский вестник» и др., «Нива»

\footnotetext{
${ }^{*}$ Corresponding author

E-mail addresses: adrianmaricka@mail.ru (A.A. Avdashkin)
} 
издавалась регулярно, постоянно наращивая тираж: к началу XX в. он составлял более 200 тыс. экземпляров. Благодаря довольно качественному контенту, многочисленным изображениям и относительно низкой подписной цене, журнал быстро завоевал популярность у широкой аудитории, принадлежавшей к разным сословиям и политическим взглядам. Он позиционировал себя как издание для семейного чтения, которое «не допускало ничего противного требованиям религии и нравственности..., никакой полемики, проистекающей из борьбы политических мнений и социальных вопросов». Специфика «Нивы» дает возможность предположить, что она отражала взгляды широкой части образованного российского общества и, в свою очередь, оказывала влияние на формирование ее представлений. На основе материалов журнала возможна достоверная реконструкция наиболее массового образа «другого» в лице китайцев.

В основу работы положен метод исторической имагологии. Образы китайских мигрантов интерпретируются как одно из проявлений «образа другого», играющего важную роль в истории многих культур. У каждой из них есть образ «Другого», выполняющий важную роль в игре смыслов и значений, определяющих ее Я-концепцию» (Журавлева, 2021: 12). Сочетание контент- и дискурсанализа позволяет определить частотность тех или иных вербальных конструкций в больших текстовых массивах, выявить устойчивые обороты, характеризующие особенности восприятия «образа другого», как в общественном сознании, так и в официальном государственном дискурсе, выявить языковые конструкции, ключевые для формировании «образа другого». В работе с художественными текстами доказал свою высокую научную эффективность метод литературоведческого анализа, а при изучении эго-документов - биографический и историкокультурный методы.

\section{3. Обсуждение}

На рубеже XIX-XX вв. Китай и мигранты из стран Азии воспринимались отечественными политиками, исследователями и публицистами в основном как источник угрозы (См.: Дятлов, 2000$).$ Так, в российском публичном пространстве впервые появилось и обрело широкое употребление понятие «желтая опасность» как иносказание «о набеге народов желтой расы на Европу» (Михельсон, 1902: 225). Организация «желтого труда» и предотвращение «желтой угрозы» обрели мощное влияние на общественно-политическую ситуацию, способствуя разработке проектов «защиты» рынка труда и границ (Левитов, 1900; Панов, 1912).

Несмотря на скудость источников, современники оставили немало информативных описаний социальной организации китайской общины в России (Шрейдер, 1897; Граве, 1912). После войны с Японией идея «экономического освобождения от желтых» занимала все более видное место в политической повестке (Унтербергер, 1912). Первая мировая война и революция в России на долгие годы изменили ракурсы восприятия восточного соседа, а новый всплеск интереса к образам китайцев произошел только после распада СССР.

В современной научной литературе к исследованию образов Китая и китайских мигрантов конца XIX - начала XX вв. обращались многие ученые (Лукин, 2004; Дятлов, 2010; Титаренко, 2014). Образ китайцев, выработанный в позднеимперской России, характеризовался как противоречивый, сочетающий, казалось, несовместимые черты. Так оформилась его несущая конструкция: обезличенность, неприхотливость, антисанитария и нищета, «заискивающая» модель поведения, высокая конкурентоспособность и быстрое освоение новых сфер деятельности (Восток России..., 2011: 464).

Значительный пласт литературы посвящен отражению событий боксерского восстания в печати и карикатурах (Eskridge-Kosmach, 2013; Старовойтова, 2017). Восстание ихэтуаней и Русско-японская война 1904-1905 гг. существенно расширили сферу применения термина «желтые» в публичном пространстве Российской империи (Гузей, 2013: 174). Пристальное внимание уделяется историками развитию дискуссий о «желтой опасности», их долгосрочному влиянию на язык описания китайских мигрантов (Dyatlov, Dyatlova, 2020), внутреннюю и внешнюю политику России и европейских держав (Odijie, 2017; Авилов, 2020).

В трудах, подготовленных в последние десятилетия, показано, как китаефобию подпитывали ощущения слабости контроля над дальневосточными окраинами, страхи перед китайцами как сильным конкурентом в сфере предпринимательства, освоения природных богатств обширного края и др. (Yin Hsu, 2006; Дятлов, 2000; Ходяков, 2018). Уже подробно реконструированы особенности трудовой миграции китайцев в годы Первой мировой войны и реакция российского общества на вынужденное расширение географии применения «желтого труда» (Alexeeva, 2018; Ходяков, 2019а). В сложившейся историографической ситуации все более пристальное внимание уделяется технологиям создания образа «другого» в периодической печати второй половины XIX - начала XX вв.

\section{4. Результаты}

О Китае и китайцах длительное время практически ничего не было известно. Уважение и признание успехов развития, достигнутых задолго до европейцев, соседствовали с пренебрежением. Как сказано в одной из заметок «Нивы», «китайцы изобрели порох. Книгопечатание и компас были известны им задолго до нас. Они же ввели в употребление фарфор и шелковые ткани. Во всех же 
остальных отношениях это ничтожная нация, которая питается рисом, крысами и собачьим мясом, а гостям преподносит змеиные яйца и жаркое из ящерицы. Вот все, или почти все, что нам было до сих пор (1887 г.) известно об обитателях Небесной Империи» (Нива, 1887: 1123).

В этом сложном контексте происходило складывание образа Китая и китайцев. Отпечаток накладывала краткость периода, в ходе которого шло его формирование, эпизодичность и локальность контактов между сторонами. Все это делало образ Китая и китайцев амбивалентным и лишенным бинарности. Отдельные его черты при определенных обстоятельствах приобретали положительную коннотацию, в иных случаях интерпретировались отрицательно и воспринимались как угроза.

Характер публикаций «Нивы» второй половины XIX - начала XX вв. позволяет проследить динамику отношения авторов и части аудитории издания к проблеме российского присутствия на Дальнем Востоке. Если в публикациях 1880-х - 1890-х гг. транслировалась тревога относительно беззащитности границ в регионе, господства в нем китайцев (См.: Максимов, 1880; 1881; Ингеницкий, 1897), то на рубеже XIX-XX вв. на первый план выдвинулся успешный опыт освоения Дальнего Востока и Ляодунского полуострова (появление каменных зданий, развитие торговли, строительство железных дорог и, главное, переселение тысяч людей всевозможных профессий) (Нива, 1899; Орлов, 1902). Однако после поражения России в русско-японской войне авторы «Нивы» оценивали притязания на Маньчжурию как авантюризм, приведший к позору и жертвам, сокращению возможностей для освоения богатств собственных территорий, осложнению отношений с Китаем (Нива, 1907).

Последствия Синьхайской революции, падение Цинской династии вновь актуализировали претензии на Маньчжурию. На страницах журнала зазвучали призывы к российской власти стать просветителем и устроителем жизни народов Востока, активизировать моральные силы и необычайные ассимилирующие способности русского народа (Нива, 1912). Тем самым вопрос о том, где пределы Российской империи и где заканчивается «наша» земля на востоке, остался открытым.

Отчасти его решению препятствовало представление об особой роли России в Азии, отличной от хищнической политики других западных держав. В публикациях «Нивы» подчеркивался миролюбивый характер российских действий, невмешательство во внутреннюю политику Китая, уважение к местным традициям, религиозным верованиям и др. Это, по мнению авторов, давало Российской империи исключительную возможность исполнить культурную миссию сближения европейцев и азиатов, способствовать распространению доверия и дружбы между ними, транслировать передовые европейские достижения (Орлов, 1902).

Противоречивые представления о российском присутствии на Дальнем Востоке умножались на неоднозначный опыт непосредственных контактов русских и китайцев. Собственный корреспондент «Нивы» В.А. Табурин, проведший в Китае более года, так охарактеризовал типичное отношение русских офицеров и солдат к местному населению: «Признавать за китайцем человеческие права считается наивностью и слабостью, потому что это не человек, а животное» (Табурин, 1905).

Главными, пугающими авторов «Нивы» отличиями, были многочисленность населения Китая и отсутствие у него черт, по их мнению, неотъемлемо присущих всем людям. В тематических статьях даже одного номера численность китайцев определялась как в 300 млн, так и в 600 млн человек. Эта неисчислимая масса людей не имела страха смерти, обладала неиссякаемым трудолюбием, живучестью и аскетизмом, уникальными способностями к адаптации. Такие представления о китайцах, как машинах «без чувств и без нервов» (Миль, 1913), транслировались аудитории «Нивы». Представления авторов относительно стратегий взаимодействия с ними пролегали в широком диапазоне - от призывов к укреплению европейского единства и подготовке к столкновению с «желтой опасностью» до предложений сближения с Китаем, узнавания его культуры и выстраивания отношений на мирной, взаимоуважительной основе.

Страх, присущий восприятию китайцев русскими, сопровождался сложной гаммой чувств, включающей типичное для к. XIX - н. XX вв. высокомерие европейца перед «ничтожным азиатом». Оно проявлялось в уничижительных обращениях («макаки», «бродяги», «китаёзы») и одновременно - в раздражении, обиде и растерянности в ответ на ненависть к иностранцам («заморским чертям») (Нива, 1876; Нива, 1882).

Конструирование образа начиналось с репрезентации внешнего облика и образа жизни китайца. Благодаря сотрудничеству с художниками-иллюстраторами, «Нива» давала возможность своей аудитории не только прочитать об этом, но и взглянуть на изображения китайских мандаринов, крестьян, торговцев, типичные бытовые сцены. Это оживляло образ, делало его более многогранным. В нем отчасти воспроизводились стереотипные представления об уродстве китайцев (Максимов, 1881), но они дополнялись описаниями умных красивых лиц и хорошо сложенных фигур: «Китайцы как тип гораздо совершеннее японцев. Они выше ростом, лучше сложены. В них видна порода» (Табурин, 1904c: 954).

Нашла свое отражение в публикациях «Нивы» тема антисанитарии (китаец никогда не покидает своей одежды, это она его покидает) (Нива, 1913а: 720). Грязь, мрачность, теснота в китайских поселениях увязывалась авторами с нищетой, бесправием значительной части населения и 
жесточайшей эксплуатацией со стороны цинских властей. При этом подчеркивалось колоссальное трудолюбие, умеренность китайцев, их необычайное терпение и настойчивость, хитрость и алчность.

Столь же противоречиво описывался быт китайцев. Жилище китайца «покрыто грязными одеялами, лоснящимися от жирной грязи». Зимою под лежанку, расположенную в центре дома, ставится жаровня с пылающими углями, от чего «смрад распространяется по всему дому». Отсутствие отхожих мест приводило к тому, что все вокруг оказывалось «загажено» и «заражено». В этих условиях беспрерывно свирепствовали эпидемии, что преподносилось и как фактор, способствующий высокой «живучести китайской расы». При огромной рождаемости те, кто в детстве пережил эпидемии, становятся устойчивы к болезням и этим «застрахованы от смерти» (Нива, 1913а). Контрастируют с этими мрачными картинами описания просторных, красиво убранных домов китайских крестьян, заметки о достижениях традиционной медицины (Нива, 1893: 906).

Образ китайцев рассматривался вне привычного современникам конфессионального континуума. Религиозность представителей «желтой расы» являлась важным маркером их архаичности, отсталости от остального «культурного мира». «Другой» в лице китайцев и японцев жил в атмосфере «религиозной пустоты». За все время мы обнаружили только одну заметку, посвященную их религиозным верованиям. С первых строк сказано: «...Китайцы и японцы в религиозном отношении стоят на очень низкой ступени, а их верования крайне примитивны и детски наивны». Это иллюстрируется устрашающими фотографиями китайских «кумирен», мучений, ожидающих китайца за грехи. Как резюмировал автор «насчет всяких мучительств, фантазия китайцев неистощима» (Нива, 1905а).

Обычаи и традиции китайцев привлекали европейцев своей причудливостью. Маркируя их как жестокие, варварские и примитивные, некоторые корреспонденты «Нивы» старались увидеть в них рациональное зерно, понять историческую и религиозную обусловленность. Так, описывая обычай хоронить заживо преступников, неисправимых игроков, курильщиков опиума, прокаженных, автор объяснял его заботой о близких и устранением опасного человека из общества, а также религиозными верованиями китайцев, которые убеждены, что после смерти человек будет располагать тем же телом, с которым принял смерть. Дикий, с точки зрения европейца, обычай интерпретировался как приемлемый вид казни (Нива, 1893: 905-906).

В публикациях об устройстве китайского общества и семейных традициях читатели узнавали, что даже беднейший из крестьян мог получить образование в Китае, сдать экзамены и претендовать на государственные должности, а знатность человека зависела только от его личных заслуг и детям не передавалась. Все члены китайской семьи должны были оказывать друг другу помощь и покровительство (Штельцнер, 1887).

Несущей конструкцией образа Китая в российском массовом сознании являлись представления о неподвижной, спящей «Желтой империи» и «пробуждающемся Драконе». В единый комплекс их собирал нарратив о том, что еще в древности Китай достиг высокого уровня развития культуры, став самым просвещенным государством мира. Затем он словно застыл в «неподвижности» и отстал от передовых стран Запада. Такой «метарассказ» не отягощался поиском причин того, почему произошло «торможение» некогда успешной державы, но дополнялся представлением об исключительной способности Китая учиться у Европы, перенимая и усваивая ее достижения. Толчок, полученный Срединной империей от передовых стран, помноженный на ее «многотысячелетний опыт и умение бесследно переживать даже самые страшные потрясения», обусловил быстрый рывок Китая по пути обновления и превращения в одно из самых мощных государств. Это убеждение составило основу концепта о «пробуждении Дракона», о котором немало писала «Нива» (Нива, 1906а: 622; Нива, 1910: 457). Лишь после Синьхайской революции стали высказываться сомнения относительно способности Китая усваивать западный опыт (Нива, 1913b: 939-940).

Представление об устойчивости китайской цивилизации формировало у европейцев ощущение неразрушимости и нераспадаемости Китая, даже при слабой маньчжурской власти и колонизационном давлении. Автор одного из немногих экспертных материалов «Нивы», исследователь Японии и Дальнего Востока П. Чечин, в качестве факторов прочности единства Китая указывал огромность и однородность населения, способность «окитаивать» иностранцев. В случае, если какая-то держава рискнет овладеть Китаем, она будет поглощена «желтым морем населения» (Чечин, 1913).

Страх перед «пробуждающейся» и неодолимой Китайской империей, надвигающейся на Европу и Россию «желтой опасностью», заставляли размышлять о воинственности китайцев. Журнал «Нива» не раз сообщал читателям о миллионной армии Китая, ее реформировании по западным образцам. Однако доминировало представление о военной слабости и трусости китайцев: «...их солдаты хилые, болезненные, калеки. На эту службу берут людей окончательно ни к чему неспособных. Военная служба считается унизительной. Нация с такими воззрениями не может быть воинственной» (Табурин, 1904с: 954). Другой автор пояснял причину подобного положения дел противоречием военного духа китайской философии, традициям, идеям и нравам народа. Более опасным ему виделся мирный Китай - непобедимый в борьбе за свое существование (Нива, 1885: 987). 
При описании действий великих держав и России в Китае, вызванных восстанием ихэтуаней, первостепенная роль отводилась обоснованию высокой цивилизаторской и христианской миссии России. Так, при назначении маршала Вальдерзее командующим войсками Альянса восьми держав, боровшихся с восставшими, заявлялось, что Россия ограничила свободу его действий «лишь нравственным требованием соблюдать человеколюбивые христианские заветы, которых придерживается Россия не только в мирное время, но и на войне» (Нива, 1900g: 662). Ведь именно спасение христиан, гонимых китайцами, презентовалось одной из основных целей борьбы русского военного контингента в Китае (Нива, 1900d: 563).

Акцентировалось немалое внимание и на ведущей роли России в «китайских делах», поскольку всякая катастрофа в «Небесной империи» напрямую касалась ее интересов (Нива, 1900а: 504). Особо подчеркивалось, что с союзными войсками сражается не весь Китай, а именно движение «Большого кулака» - партия враждебная иностранцам (Нива, 1900f: 601). Так очерчивались политические границы конфликта, не акцентируя его конфессиональный или цивилизационный характер. Русский солдат, суворовский «чудо-богатырь», героически проявлявший себя в боях с шайками китайских разбойников-хунхузов, одновременно был милосерден к страдающему народу, нищим и сиротам в Китае. На страницах журнала не раз встречались истории о китайских «детях полка», взятых на воспитание русскими солдатами и матросами (Нива, 1900k: 1004; Нива, 1902: 342-343).

Основной причиной происходивших в Китае событий показан тяжелый внутриполитический кризис империи Цин, противоборство между немногочисленными сторонниками «просвещения» и народными массами, выступающими за сохранение прежних устоев. Это преподносилось как борьба цивилизации и варварства, современности и прошлого. Тем самым «Небесная империя» ставилась перед вопросом: остаться «недвижимой» или последовать примеру Японии и приобщиться к европейской культуре (Нива, 1900с: 542). Завершение вооруженной борьбы и начавшееся урегулирование положения трактовались как первый шаг к разрушению преград, которые отделяли Китай от «культурного мира» (Нива, 1900ј: 864).

Тексты и визуальные дополнения к ним показывали сторонников движения «Большого кулака» в образах средневековых воинов, вооруженных копьями, луками и саблями. С помощью иллюстраций подчеркивалось их сходство с варварами-кочевниками (Нива, 19о0с: 6о2; Нива, 190оf: 544). Иллюстрации, опубликованные в материалах о восстании боксеров, демонстрировали читателям дикость, нецивилизованность и варварство китайцев. Эту же роль играли изображения публичных казней иностранцев и плакат движения «Большого кулака», призывающий убивать иноземцев (Нива, 1900d: 564; Нива, 1900і: 781). На нем детально изображены пытки, применявшиеся восставшими к «заморским дьяволам». Особо подчеркивалась многочисленность мятежников («громадные полчища, толпы и скопища»), но они в силу приписанной им архаичности оказались плохо вооружены, слабо организованы и небоеспособны, поэтому быстро обращались в бегство даже без боя (Нива, 1900g: 661-664).

Китайская миграция характеризовалась не как социальный процесс, а скорее как стихийное бедствие («наплыв», «переселение целыми массами», «желтый потоп»). Со страниц «Нивы» все более настойчиво звучали опасения того, что многочисленная «желтая раса» может усилиться, объединиться, а затем разгромить и поработить Европу, как когда-то монголы - Русь, разделенную на удельные княжества (Нива, 1895: 390). Транслировалась мысль о необходимости сплочения европейских держав перед лицом опасности с Востока. В особенности после победы Японии в русскояпонской войне, когда «желтый мир» почувствовал свою силу», а Россия оказалась перед лицом «желтой опасности» (Нива, 1905b). Тем не менее расистский дискурс в его крайнем выражении, настаивающий на тотальной природной несовместимости «желтой» и «белой» рас, которая не предполагала возможности мирного сосуществования (См.: Дятлов, 2014: 24), не был характерен для материалов «Нивы».

Современники осознавали, что, с одной стороны, «желтая» рабочая сила являлась жизненно важной для строительства экономической и военной инфраструктуры на Дальнем Востоке (Ходяков, 2019b: 999), с другой - привлечение большого количества «желтых» рабочих создавало серьезные препятствия для заселения региона русскими, вело к его постепенному окитаиванию. Все эти оценки, колебавшиеся от пренебрежения к китайцам до ощущения зависимости от их труда, формировали противоречивую оптику восприятия «желтого труда».

Конкуренция местных рабочих с китайцами на рынке труда признавалась невозможной, поскольку белый рабочий не мог «жить в грязи и питаться горстью риса». К остальным категориям китайцев, изображенным на страницах «Нивы», относились банды хунхузов и хищникизолотоискатели («сброд», «скопища», «чуждые», «нашествие китайской сволочи») (Нива, 1881: 930-932). Вот один из характерных отрывков: «Несметные толпы желтого пролетариата идут на заработки в пределы России..., китайцы, как более приспособленные к местным условиям и более сильные хозяева, оказываются наиболее способными колонизаторами и настоящими завоевателями. Волна китайских переселенцев страшнее китайских армий» (Нива, 1908: 302).

Концепция о «желтой опасности» предполагала визуализацию территориальных плацдармов экспансии. «Китайский» квартал и «китайская» улица получили множество детальных описаний в

$$
-1902-
$$


публицистике того времени. При этом тональность текстов варьировалась от восторга прикосновения к экзотике и посещения настоящего Китая до «разбойного логова», «улья», «клоаки», «дна». «Китайский квартал» расценивался как логичное продолжение организации пространства в самом Китае. Вот короткое описание одной из типичных улиц в китайском городе: это непременно «грязные, узкие и извилистые улочки, покрытые толстым слоем черной пыли», китайское жилище всегда до ужаса грязно, мрачно, темно и печально (1900. № 26; 1913. № 36).

С началом русско-японской войны почти в каждом номере «Нивы» в рубрике «Политическое обозрение» публиковались тексты под заголовками «Отклики войны», посвященные патриотическим настроениям в тылу, описанию состояния русской и японской армий и т.д.; в рубрике «С театра военных действий» появлялась хроника происходящего с обязательными портретными и видовыми изображениями, «Державы и война» освещала положение в мировой политике. С марта 1904 г. журнал организовал сбор средств на нужды армии и флота и в пользу раненых.

В первые месяцы войны многие тематические материалы «Нивы» полностью или частично представляли собой перепечатки из «Правительственного вестника» и были проникнуты официозом. Но уже в мартовском номере 1904 г. редакция сообщила об отправке на театр военных действий собственных корреспондентов - В.А. Табурина, постоянного сотрудника «Нивы», довольно известного иллюстратора и прозаика (близкого к литературно-общественному кругу В.Г. Короленко и М. Горького), и В.К. Буллу, фотографа, сына знаменитого петербургского фотодокументалиста К. Буллы. Их первые репортажи из Иркутска появились в апрельском выпуске журнала.

В текстах о войне патриотический подъем и возмущение вероломством Японии первоначально вытеснили «китайскую тему», несмотря на то, что конфликт развернулся именно в Китае. Маньчжурия для авторов публикаций этого периода представлялась как «самая отдаленная часть нашей территории» (Нива, 1904а: 136). С марта 1904 г., наряду с сообщениями о перемещениях войск, высоком боевом духе русских солдат и непременной победе над Японией, появились заметки о трагических последствиях войны: эвакуации населения из прифронтовой полосы, хаосе и беспорядке при выезде, личных трагедиях людей, штурмующих билетные кассы, бросающих багаж, который не удавалось взять в вагон, голоде в пути (Нива, 1904b).

В это же время встречаются и первые упоминания о китайцах в материалах «Нивы», где их обвиняли в шпионаже в пользу японцев, подавая это как важную причину успехов последних, но подчеркивали, что «простой народ» все же симпатизировал русским. Чуть позже в журнале поместили большой текст, в котором осмысливалась не только общая расстановка сил в условиях войны, но и позиция Китая в противостоянии России и Японии. Тревогу авторов вызывала проблема сохранения китайского нейтралитета. Доминирующее в российском политическом дискурсе представление о тайной помощи Китая японцам позволяло утверждать, что открытое союзничество «желтых империй» для России менее опасно, т.к. Китай в военном отношении довольно слаб. Ответить на объединение сил азиатских держав автор призывал сплочением европейских стран по примеру коалиции 1900 г., а после ее победы окончательно разделить Поднебесную. Тем самым предполагаемое развитие военных действий с включением в них Китайской империи и превращением конфликта России и Японии в противостояние Востока и Запада вписывалось в идеологему о «желтой опасности».

Однако полной уверенности в том, что роковой час столкновения «белой» и «желтой» рас действительно настал, у автора не было. Он допускал сохранение Китаем нейтралитета, что способствовало бы развитию дружеских отношений держав и приносило выгоду и России, закреплявшей за собой свободный выход к незамерзающим портам Тихого океана, и Китаю, избавленному от новых территориальных притязаний (Нива, 1904c).

После сражений весны-лета 1904 г. тон журнальных публикаций начал меняться. Акцент смещался на японские успехи и их причины: хорошо поставленную разведку, умелое применение артиллерии и коммуникаций на воинских позициях, позволяющих координировать действия и т.д. Шапкозакидательские настроения по поводу судьбы Порт-Артура сменились тревогой, отмечались большие потери, которые несли японцы и русские. Но заметки о поражениях русской армии уравновешивались сведениями о локальных успехах, примерами героизма и благородства русского солдата, описаниями мощи защитников Порт-Артура. Продолжающееся отступление войск А.Н. Куропаткина подавалось как реализация стратегического плана командования. «Японцы - это враг опасный своею хитростью, тщательной подготовкой к войне, но не страшный, - утверждалось в одном из текстов «Нивы», - у него нет надлежащей отваги, он раб плана и базы» (Нива, 1904f: 594).

Благодаря В.А. Табурину, на страницах журнала регулярно появлялись очерки, посвященные жизни местного населения в условиях войны, быту российских офицеров и солдат, взаимоотношениям китайцев и европейцев. Его острый взгляд публициста точно подмечал высокомерие и презрение, с которым «белые» обращались к местным, но оно отнюдь не свидетельствовало об их превосходстве, а скорее наоборот:

Публика в Ин-коу, восседающая на террасе [ресторана] «Манчжур-Гауза» развлекается иногда бросанием мелких денег в толпу проходящих кули. Полуобнаженные, коричневые тела набрасываются на мелькнувший в воздухе двугривенный с таким азартом и с таким упорством 
борются в общей массе, давя друг друга, что, кажется, не обойдется дело без полома рук и ног. На самом деле все обходится благополучно и не переходит в драку. Монеты делятся между всеми поровну..., для чего же столько азарта? А очень просто - если бы монеты просто подымались и делились, иностранцы перестали бы их бросать. Кто дикарь в этом случае - кули или европеец? (Табурин, 1904а: 610).

Проникнувшись переживаниями населения Поднебесной, Табурин объяснял, что шпионаж и предательство китайцев, столь болезненные для русских, это результат тяжелого и двусмысленного положения, в котором оказались мирные манзы ${ }^{1}$. Они, не поддерживая ни одной из воюющих сторон, находятся в районе военных действий и бывают свидетелями операций неприятеля. Это используют и русские, и японцы, насилием и страхом добывая сведения у китайцев. Добровольно же они шпионят редко, а если служат русским (переводчиками, проводниками и даже добровольцами), то всегда верно и преданно. Большинство мирных китайцев старались укрыться в горах (Табурин, 1904а).

В очерках о Китае страдания местного населения от войны, разрушающей их хозяйство, разоряющей дома, от насилия и несправедливости, уничижительного отношения к ним европейцев становятся для Табурина лейтмотивом. Он описывает пытки и убийства мирных китайцев как японцами, так и русскими, мародерство солдат, хозяйничанье в деревнях и требование от жителей прислуживать военным, презрение к культуре Китая и нежелание учить китайский язык и т.д. При этом не только из гуманистических побуждений, но и здравого политического расчета он призывал относиться к китайцем человечно. По его мнению, в условиях войны это позволило бы избежать шпионажа, а в целом, в отношениях китайцев к русским преодолеть недоверие и затаенную злобу (Табурин, 1904b; Табурин, 1905a; Табурин, 1905b).

В августе-сентябре 1904 г. произошел определенный перелом в журнальной риторике о войне. После сражения под Ляояном, на которое пришелся пик публикаций, их количество снижается. Все чаще начинает звучать мысль о возможной сдаче Порт-Артура, тяжелых последствиях поражений и отступлений для боеспособности армии и российского общества, а после Мукдена - о просчетах командования. На первый план постепенно выдвинулась тема мирных переговоров и последствий войны. Дискурсивной рамкой для ее обсуждения продолжала оставаться идея «желтой опасности».

Неслучившаяся победа России, которая должна была не допустить подъема и сплочения Азии, воспрепятствовать распространению панмонголизма (Нива, 1904g), по мнению авторов «Нивы», лишь отдалила момент «столкновения цивилизаций» и обусловила поиск новой европейской стратегии, средств сдерживания «желтого моря». Одним из таких способов представлялось налаживание дружеских и миролюбивых российско-китайских отношений. За Китаем признавалось право считать себя «обиженною и пострадавшею стороной», а потому, утверждал корреспондент журнала, в ходе мирных переговоров и дальневосточной политике России, в целом, не принимать в расчет желаний пробуждающегося к политической жизни четырехсотмиллионного народа было бы недальновидно (Нива, 1905с: 560).

Само завершение русско-японской войны и условия Портсмутского договора оценивались поразному. Некоторые считали выход России из войны благом, ведь в противном случае страна продолжала бы страдать от кровопролития, колоссальных военных расходов и риска новых неудач, не обладая достаточной боевой мощью армии и флота, путями сообщения с театром военных действий и т.д. Мирные условия казались им не столь уж обременительными и невыгодными, т.к. уступленные территории не имели большого практического значения, их богатства слабо разрабатывались и не оправдывали значительных расходов по их управлению (Нива, 1905d: 718). Другие авторы шли дальше, утверждая, что поражение России, эта «великая национальная беда», была закономерным исходом авантюристичной политики (Нива, 1905g).

На страницах журнала высказывались и иные позиции. Причем они становились заметнее, чем более исторически отдалялись события русско-японской войны, а революция в России утихала. Речь, в частности, шла о преждевременном заключении Портсмутского договора и необходимости Российской империи продолжать войну (Нива, 1906b: 91), а также об эффектах и символическом значении японской победы, пробудившей дремлющую гордыню Азии. Авторы подобных текстов предрекали опасность нового столкновения цивилизаций и призывали российские власти основывать свою политику «на прочных расчетах предвидения и заранее готовиться к тяжелой и трудной борьбе, которая уготована нашим детям деяниями их отцов» (Нива, 1905f: 738).

К концу 1905 года тема русско-японской войны вытесняется из повестки журнала иными проблемами, однако в течение нескольких лет после заключения мира на страницах «Нивы» продолжали появляться изображения российских участников войны и батальных сцен.

\section{5. Заключение}

Журнал «Нива» создавал для своих постоянных читателей понятный образ Китая и его жителей. Однако эти образы были многогранны и динамичны, меняясь в зависимости от внутриполитической ситуации в Российской империи и событий, происходивших на международной

${ }^{1}$ Китайское население Маньчжурии. 
арене. Но всякий раз данные образы оставались ярким воплощением «другого», инструментальная роль которого состояла в формировании у широких слоев населения собственной идентичности. Важное место в публикациях «Нивы» отводилось визуальным и антропологическим характеристикам китайцев. При этом умело задействовались стереотипные представления о китайцах, существовавшие у населения империи еще до появления журнала, эти шаблоны укреплялись и расширялись, встраивались в новый исторический контекст.

\section{6. Благодарности}

Исследование проведено при финансовой поддержке Министерства науки и высшего образования Российской Федерации (проект № FENU-2020-0021).

\section{Литература}

Авилов, 2020 - Авилов Р.С. «Какой вздор!»: военный министр А.Н. Куропаткин о трудах японских националистов // Новейшая история России. 2020. № 4. С. 875-891.

Восток России..., 2011 - Восток России: миграции и диаспоры в переселенческом обществе. Рубежи XIX-XX и XX-XXI веков / Научный редактор В.И. Дятлов. Иркутск, 2011. 624 с.

Граве, 1912 - Граве В.В. Китайцы, корейцы и японцы в Приамурье. СПб., 1912.

Гузей, 2013 - Гузей Я.С. Категория «желтые» в контексте расового дискурса в Российской империи в конце XIX - начале XX в. // Известия Иркутского государственного университета. Серия «Политология. Религиоведение». 2013. № 2. С. 167-178.

Дятлов, 2000 - Дятлов В.И. Миграция китайцев и дискуссия о «желтой опасности» в дореволюционной России // Вестник Евразии. 2000 . № 1. С. 63-89.

Дятлов, 2010 - Дятлов В.И. «Великие ксенофобии»: взаимовлияние и взаимодействие (опыт России) // Идеи и идеалы. 2010. № 2. Ч. 1. С. 51-63.

Дятлов, 2014 - Дятлов В.И. Экзотизация и «образ врага»: синдром «желтой опасности» в дореволюционной России // Идеи и идеалы. 2014. № 2. С. 23-41.

Журавлева, 2021 - Журавлева В.И. Понимание России в США: образы и мифы.1881-1914. М., 2021.

Ингеницкий 1897 - Ингенццкий И.В. Два дня в Китае. Из путевых заметок // Нива. 1897. № 49. C. $1166-1167$.

Левитов, 1900 - Левитов И. Желтая раса. СПб., 1900.

Левитов, 1905 - Левитов И. Желтороссия, как буферная колония. СПб, 1905.

Лукин, 2004 - Лукин А.В. Образ Китая в российском общественном сознании: преемственность и эволюция // Полис. 2004. № 6. С. 70-88.

Максимов, 1880 - Максимов А.Я. По поводу последних событий на китайской границе // Нива. 1880. № 22. С. $442-443$.

Максимов, 1881 - Максимов А.Я. На острове Аскольде // Нива. 1881. № 42. С. 930-932.

Милль, 1913 - Милль П. Китаец (рассказ) // Нива. 1913. № 22. С. 435-437.

Михельсон, 1902 - Михельсон М.И. Русская мысль и речь. Свое и чужое. Опыт русской фразеологии: сборник образных слов и иносказаний. СПб., 1902.

Нива, 1876 - Нива. 1876. № 20.

Нива, 1881 - Нива. 1881. № 42.

Нива, 1882 - Нива. 1882. № 41.

Нива, 1885 - Нива. 1885. № 41.

Нива, 1887 - Нива. 1887. № 45 .

Нива, 1893 - Нива. 1893. № 40.

Нива, 1895 - Нива. 1895. № 16.

Нива, 1899 - Нива. 1899. № 27.

Нива, 1900а - Нива. 1900. № 25.

Нива, 1900b - Нива. 1900. № 26.

Нива, 190ос - Нива. 1900. № 27.

Нива, 1900d - Нива. 190о. № 28.

Нива, 1900 - Нива. 1900. № 30.

Нива, 1900g - Нива. 1900. № 33 .

Нива, 190оі - Нива. 1900. № 39 .

Нива, 1900ј - Нива. 1900. № 43.

Нива, 1900k - Нива. 1900. №50.

Нива, 1902 - Нива. 1902. № 17.

Нива, 1904а - Нива. 1904. №7.

Нива, 1904b - Нива. 1904. № 12.

Нива, 1904c - Нива. 1904. № 19.

Нива, 1904f - Нива. 1904. № 30.

Нива, $1904 \mathrm{~g}$ - Нива. 1904. № 47. 
Нива, 1905а - Нива. 1905. № 6.

Нива, 1905b - Нива. 1905. № 20.

Нива, 1905с - Нива. 1905. № 28.

Нива, 1905d - Нива. 1905. № 36.

Нива, $1905 \mathrm{f}-$ Нива. 1905. № 37.

Нива, 1905g - Нива. 1905. № 41.

Нива, 1906а - Нива. 1906. № 6.

Нива, 1906b - Нива. 1906. № 39 .

Нива, 1907 - Нива. 1907. № 8.

Нива, 1908 - Нива. 1908. № 16.

Нива, 1910 - Нива. 1910. № 25.

Нива, 1912 - Нива. 1912. № 30.

Нива, 1913а - Нива. 1913. № 36.

Нива, 1913b - Нива. 1913. № 47.

Панов, 1912 - Панов А.А. Борьба за рабочий рынок в Приамурье. СПб., 1912.

Орлов, 1902 - Орлов В.И. Город Дальний (очерк) // Нива. 1902. № 23. С. 454-456.

Старовойтова, 2017 - Старовойтова E.O. «Мой большой кулак еще при мне!»: боксерское восстание в Китае в российских сатирических изданиях начала ХХ века // Новейшая история России. 2017. № 2. С. 81-97.

Табурин, 1904а - Табурин В.А. На войне // Нива. 1904. № 31. С. 610-614.

Табурин, 1904b - Табурин В.А. На войне // Нива. 1904. № 34. С.672-673.

Табурин, 1904c - Табурин В.A. Война // Нива. 1904. № 48. С. 954-959.

Табурин, 1905а - Табурин В.A. На войне // Нива. 1905. № 7. С. 129-131.

Табурин, 1905b - Табурин B.A. Презренная китайщина // Нива. 1905. № 46. С. 897-902.

Титаренко, 2014 - Титаренко А.C. Представления о Китае в русском народном сознании (вторая половина XIX - начало XX в.) // Известия Уральского федерального университета. Сер. 2 «Гуманитарные науки». 2014. № 2. С. 243-251.

Унтербергер, 1912 - Унтербергер П.Ф. Приамурский край, 1906-1910 гг. СПб., 1912.

Ходяков, 2018 - Ходяков М.В. Желтороссия конца XIX - начала XX века в геополитических планах русской военной элиты // Новейшая история. 2018. № 4. С. 880-897.

Ходяков, 2019а - Ходяков M.В. Российское законодательство начала ХХ века об использовании желтого труда в экономике Дальнего Востока // Вестник Томского государственного университета. История. 2019. № 6о. С. 78-83.

Ходяков, 2019b - Ходяков М.В. Попытки рабочей колонизации восточных окраин империи в начале XX в. По документам Российского государственного исторического архива Дальнего Востока // Вестник архивиста. 2019. № 4. С. 995-1006.

Чечин, 1913 - Чечин П. Будущность Китая (очерк) // Нива. 1913. № 31. С. 615-617.

Шрейдер, 1897 - Шрейдер Д. Наш Дальний Восток. СПб., 1897.

Штельцнер, 1887 - Штельцнер А. Новейшие сведения о «Срединном царстве». Из записок китайца // Нива. 1887. № 45. С. 1123-1124.

Alexeeva, 2018 - Alexeeva O.V. Experiencing War: Chinese Workers in Russia During the First World War // The Chinese Historical Review. 2018. Vol. 25. Is. 1. Pp. 46-66.

Dyatlov, Dyatlova, 2020 - Dyatlov V.I, Dyatlova E.V. From the «Influx of the Yellow Race» to «Migrant Workers»: Dynamics of the Languages for Describing Cross-Border Migrations in Russia // Journal of Siberian Federal University. Humanities \& Social Sciences. 2020. Vol. 13. No 5. Pp. $623-638$.

Eskridge-Kosmach, 2013 - Eskridge-Kosmach A. The Boxer Rebellion and the Standpoint of the Russian Press // The Journal of Slavic Military Studies. 2013. Vol. 26. Is. 3. Pp. 414-438.

Odijie, 2018 - Odijie $M$. The Fear of 'Yellow Peril' and the Emergence of European Federalist Movement // The International History Review. 2018. Vol. 40. Is. 2. Pp. 358-375.

Yin Hsu, 2006 - Yin Hsu Ch. A Tale of Two Railroads: "Yellow Labor». Agrarian Colonization, and the Making of Russianness at the Far Eastern Frontier, 1890s.1910s // Ab Imperio. 2006. № 3. Pp. $217-253$.

\section{References}

Alexeeva, 2018 - Alexeeva, O.V. (2018). Experiencing War: Chinese Workers in Russia During the First World War. The Chinese Historical Review. 25(1): 46-66.

Avilov, 2020 - Avilov, R.S. (2020). «Kakoi vzdor!»: voennyi ministr A. N. Kuropatkin o trudakh yaponskikh natsionalistov ["What nonsense!": Minister of War A. N. Kuropatkin about the works of Japanese nationalists]. Noveishaya istoriya Rossii. 4: 875-891. [in Russian]

Chechin, 1913 - Chechin, P. (1913). Budushchnost' Kitaya (ocherk) [The future of China (sketch)]. Niva. 31: 615-617. [in Russian]

Dyatlov, 2000 - Dyatlov, V.I. (2000). Migratsiya kitaitsev i diskussiya o «zheltoi opasnosti» v dorevolyutsionnoi Rossii [Migration of the Chinese and the discussion about the "yellow danger" in prerevolutionary Russia]. Vestnik Evrazii. 1: 63-89. [in Russian] 
Dyatlov, 2010 - Dyatlov, V.I. (2010). «Velikie ksenofobii»: vzaimovliyanie i vzaimodeistvie (opyt Rossii) [“Great xenophobia”: mutual influence and interaction (experience of Russia)]. Idei i idealy . 2: 51-63. [in Russian]

Dyatlov, 2014 - Dyatlov, V.I. (2014). Ekzotizatsiya i «obraz vraga»: sindrom «zheltoi opasnosti» v dorevolyutsionnoi [Rossii Exotization and the "image of the enemy": the syndrome of "yellow danger" in prerevolutionary Russia]. Idei i idealy. 2: 23-41. [in Russian]

Dyatlov, Dyatlova, 2020 - Dyatlov, V.I, Dyatlova, E.V. (2020). From the «Influx of the Yellow Race» to «Migrant Workers»: Dynamics of the Languages for Describing Cross-Border Migrations in Russia. Journal of Siberian Federal University. Humanities \& Social Sciences. 13(5): 623-638.

Eskridge-Kosmach, 2013 - Eskridge-Kosmach, A. (2013). The Boxer Rebellion and the Standpoint of the Russian Press. The Journal of Slavic Military Studies. 26(3): 414-438.

Guzey, 2013 - Guzey, Y.S. (2013). Kategoriya zheltye v kontekste rasovogo diskursa v Rossiiskoi imperii v kontse XIX - nachale XX v. [Category yellow in the context of racial discourse in the Russian Empire in the late 19th - early 2oth centuries]. Izvestiya Irkutskogo gosudarstvennogo universiteta. Seriya Politologiya. Religiovedenie. 2: 167-178. [in Russian]

Grave, 1912 - Grave, V.V. (1912). Kitaitsy, koreitsy i yapontsy v Priamur'e [Chinese, Koreans and Japanese in the Amur region]. St. Petersburg. [in Russian]

Ingenitsky 1897 - Ingenitsky, I.V. (1897). Dva dnya v Kitae. Iz putevykh zametok [Two days in China. From travel notes]. Niva. 49: 1166-1167. [in Russian]

Khodyakov, 2018 - Khodyakov, M.V. (2018). Zheltorossiya kontsa XIX - nachala XX veka v geopoliticheskikh planakh russkoi voennoi elity [Yellow Russia of the late XIX - early XX century in the geopolitical plans of the Russian military elite]. Noveishaya istoriya. 4: 880-897. [in Russian]

Khodyakov, 2019a - Khodyakov, M.V. (2019a). Rossiiskoe zakonodatel'stvo nachala KhKh veka ob ispol'zovanii zheltogo truda v ekonomike Dal'nego Vostoka [Russian legislation of the early twentieth century on the use of yellow labor in the economy of the Far East]. Vestnik Tomskogo gosudarstvennogo universiteta. Istoriya. 60: 78-83. [in Russian]

Khodyakov, 2019b - Khodyakov, M.V. (2019b). Attempts by workers to colonize the eastern outskirts of the empire at the beginning of the 2oth century. According to the documents of the Russian State Historical Archive of the Far East [Popytki rabochei kolonizatsii vostochnykh okrain imperii v nachale XX v. Po dokumentam Rossiiskogo gosudarstvennogo istoricheskogo arkhiva Dal'nego Vostoka]. Vestnik arkhivista. 4: 995-1006. [in Russian]

Levitov, 1900 - Levitov, I. (1900). Yellow race [Zheltaya rasa]. St. Petersburg. [in Russian]

Levitov, 1905 - Levitov, I. (1905). Zheltorossiya, kak bufernaya koloniya [Zheltorossiya as a buffer colony]. St. Petersburg. [in Russian]

Lukin, 2004 - Lukin, A.V. (2004). Obraz Kitaya v rossiiskom obshchestvennom soznanii: preemstvennost' i evolyutsiya [The image of China in the Russian public consciousness: continuity and evolution]. Polis. 6: 70-88. [in Russian]

Maksimov, 1880 - Maksimov, A.Ya. (1880). Po povodu poslednikh sobytii na kitaiskoi granitse [Regarding the Recent Events on the Chinese Border]. Niva. 22: 442-443. [in Russian]

Maksimov, 1881 - Maksimov, A.Ya. (1881). Na ostrove Askol'de [On the island of Askold]. Niva. 42: 930-932. [in Russian]

Mill, 1913 - Mill, P. (1913). Kitaets (rasskaz) [Chinese (story)]. Niva. 22: 435-437. [in Russian]

Mikhelson, 1902 - Michelson, M.I. (1902). Russkaya mysl' i rech'. Svoe i chuzhoe. Opyt russkoi frazeologii: sbornik obraznykh slov i inoskazanii [Russian thought and speech. Yours and someone else's. Experience of Russian phraseology: a collection of figurative words and allegories]. St. Petersburg. [in Russian]

Niva, 1876 - Niva (1876). № 20. [in Russian]

Niva, 1881 - Niva (1881). № 42. [in Russian]

Niva, 1882 - Niva (1882). № 41. [in Russian]

Niva, 1885 - Niva (1885). № 41. [in Russian]

Niva, 1887 - Niva (1887). № 45. [in Russian]

Niva, 1893 - Niva (1893). № 40. [in Russian]

Niva, 1895 - Niva (1895). № 16. [in Russian]

Niva, 1899 - Niva (1899). № 27. [in Russian]

Niva, 1900a - Niva (1900). № 25. [in Russian]

Niva, 1900b - Niva (1900). № 26. [in Russian]

Niva, $1900 c$ - Niva (1900). № 27. [in Russian]

Niva, 190od - Niva (1900). № 28. [in Russian]

Niva, 190of - Niva (1900). № 30. [in Russian]

Niva, 1900g - Niva (1900). № 33. [in Russian]

Niva, 1900i - Niva (1900). № 39. [in Russian]

Niva, $1900 j$ - Niva. (1900). № 43. [in Russian]

Niva, 1900k - Niva (1900). № 50. [in Russian] 
Niva, 1902 - Niva (1902). № 17. [in Russian]

Niva, 1904a - Niva (1904). № 7. [in Russian]

Niva, 1904b - Niva (1904). № 12. [in Russian]

Niva, 1904c - Niva (1904). № 19. [in Russian]

Niva, 1904f - Niva (1904). № 30. [in Russian]

Niva, $1904 \mathrm{~g}$ - Niva (1904). № 47. [in Russian]

Niva, 1905a - Niva (1905). № 6. [in Russian]

Niva, 1905b - Niva (1905). № 20. [in Russian]

Niva, 1905c - Niva (1905). № 28. [in Russian]

Niva, 1905d - Niva (1905). № 36. [in Russian]

Niva, 1905f - Niva (1905). № 37. [in Russian]

Niva, $1905 \mathrm{~g}$ - Niva (1905). № 41. [in Russian]

Niva, 1906a - Niva (1906). № 6. [in Russian]

Niva, 1906b - Niva (1906). № 39. [in Russian]

Niva, 1907 - Niva (1907). № 8. [in Russian]

Niva, 1908 - Niva (1908). № 16. [in Russian]

Niva, 1910 - Niva (1910). № 25. [in Russian]

Niva, 1912 - Niva (1912). № 30. [in Russian]

Niva, 1913a - Niva (1913). № 36. [in Russian]

Niva, 1913b - Niva (1913). № 47. [in Russian]

Odijie, 2018 - Odijie, M. (2018). The Fear of 'Yellow Peril' and the Emergence of European Federalist Movement. The International History Review. 40(2): 358-375.

[in Russian]

Orlov, 1902 - Orlov, V.I. (1902). Gorod Dal'nii (ocherk) [City Dalny (sketch)]. Niva. 23: 454-456.

Panov, 1912 - Panov, A.A. (1912). Bor'ba za rabochii rynok v Priamur'e [Struggle for a labor market in the Amur region]. St. Petersburg. [in Russian]

Schrader, 1897 - Schrader, D. (1897). Nash Dal'nii Vostok [Our Far East]. St. Petersburg. [in Russian]

Starovoitova, 2017 - Starovoitova, E.O. (2017). «Moi bol'shoi kulak eshche pri mne!»: bokserskoe vosstanie $\mathrm{v}$ Kitae $\mathrm{v}$ rossiiskikh satiricheskikh izdaniyakh nachala XX veka [Boxer Rebellion in China in Russian Satiric Press in the Beginning of $20^{\text {th }}$ Century]. Noveishaya istoriya Rossii. 2: 81-97. [in Russian]

Stelzner, 1887 - Stelzner, A. (1887). Noveishie svedeniya o «Sredinnom tsarstve». Iz zapisok kitaitsa

[The latest information about the "Middle Kingdom". From the notes of the Chinese]. Niva. 45: 1123-1124.

Taburin, 1904a - Taburin, V.A. (1904). Na voine [In the war]. Niva. 31: 610-614. [in Russian]

Taburin, 1904b - Taburin, V.A. (1904). Na voine [In the war]. Niva. 34: 672-673. [in Russian]

Taburin, 1904c - Taburin, V.A. (1904). Voina [War]. Niva. 48: 954-959. [in Russian]

Taburin, 1905a - Taburin, V.A. (1905). Na voine [In the war]. Niva. 7: 129-131. [in Russian]

Taburin, 1905b - Taburin, V.A. (1905). Prezrennaya kitaishchina [Despicable China]. Niva. 46: 897902. [in Russian]

Titarenko, 2014 - Titarenko, A.S. (2014). Predstavleniya o Kitae v russkom narodnom soznanii (vtoraya polovina XIX - nachalo XX v.) [Ideas about China in the Russian national consciousness (second half of the 19th - early 20th centuries)]. Izvestiya Ural'skogo federal'nogo universiteta. Ser. 2. Gumanitarnye nauki. 2: 243-251. [in Russian]

Unterberger, 1912 - Unterberger, P.F. (1912). Priamurskii krai, 1906 - 1910 gg. [Amur Territory, 1906 - 1910]. St. Petersburg. [in Russian]

Vostok Rossii..., 2011 - Vostok Rossii: migratsii i diaspory v pereselencheskom obshchestve. Rubezhi

XIX-XX i XX-XXI vekov [East of Russia: Migration and Diaspora in a Migrant Society. The frontiers of the XIX-XX and XX-XXI centuries]. nauchnyi redaktor V. I. Dyatlov. Irkutsk, 624 p. [in Russian]

Yin Hsu, 2006 - Yin Hsu, Ch. (2006). A Tale of Two Railroads: «Yellow Labor». Agrarian Colonization, and the Making of Russianness at the Far Eastern Frontier, 1890s. 1910s. Ab Imperio. 3: 217-253.

Zhuravleva, 2021 - Zhuravleva, V.I. (2021). Ponimanie Rossii v SShA: obrazy i mify. 1881-1914. [Understanding Russia in the USA: Images and Myths. 1881-1914]. Moscow. [in Russian] 


\section{Образ Китая и китайцев в позднеимперской России (по материалам журнала «Нива»)}

Андрей Александрович Авдашкин а, *,Татьяна Витальевна Раева а, Игорь Вячеславович Сибиряков а

а Южно-Уральский государственный университет, Российская Федерация

Аннотация. В данной статье предпринята попытка исследовать образы Китая и китайцев в Российской империи во второй половине XIX - начале XX веков на примере журнала «Нива», в котором публиковались новостные статьи, репортажи с места событий, портретные зарисовки, литературные произведения на «китайскую тему», биографические и этнографические очерки. Тексты и многочисленные иллюстрации позволяли знакомить широкую аудиторию с историей Китая, бытом и традициями его населения. Методологическую основу исследования составили методы исторической имагологии, контент- и дискурс-анализ. Авторы пришли к выводу, что издателям, редакторам и авторам журнала, а также, вероятно, дореволюционной российской общественности не удалось сформировать целостный образ Китая и государства Китай. В совокупности различных, порой взаимоисключающих, представлений о них в зависимости от российского и мирового общественнополитического контекста второй половины XIX - начала XX вв. некоторые элементы были обновлены. Этим объясняется непостоянство общественного мнения в России по отношению к Китаю, проблеме организации «желтого труда», что придает динамику и гибкость российской политике на Дальнем Востоке и ее репрезентациям в публичном пространстве империи. Образы китайского государства и китайцев были многогранными и динамичными, но всякий раз воплощали в себе яркие черты «другого». Его инструментальная роль заключалась в формировании у широких слоев населения Российской империи собственной идентичности. Существенную роль в публикациях «Нивы» играли визуальные и антропологические характеристики китайцев.

Ключевые слова: образ, Китай, китайцы, «Нива», «желтая опасность», миграция, Российская империя.

\footnotetext{
* Корреспондирующий автор

Адреса электронной почты: adrianmaricka@mail.ru (А.А. Авдашкин) 